\title{
Phytogeographical origin of Madeiran common beans based on phaseolin patterns
}

\author{
Emanuel Marques da Silva(1), Anísia Soraia Abreu Correia(1), Nuno Alexandre Amaral Lopes(1), \\ Humberto Gil Moreira Nóbrega(1), José Filipe Teixeira Ganança ${ }^{(1)}$, Ana Maria Domingues ${ }^{(2)}$, \\ Manhaz Khadem(1), Jan Jacek Slaski(3) and Miguel Ângelo Almeida Pinheiro de Carvalho(1)
}

\begin{abstract}
(1)Universidade da Madeira, Centro de Estudos da Macaronésia, ISOPlexis Banco de Germoplasma, 9000-390 Funchal, Portugal. E-mail: emasil2008@gmail.com, anisiacorreia@gmail.com, lopenuno@gmail.com, humberto_nobrega@yahoo.com, jofitei@gmail.com, khadem@uma.pt, quercus@uma.pt (2)Instituto de Investigação Científica Tropical, Rua da Junqueira, 86, 10, 1300-344 Lisboa, Portugal. E-mail: dam.portugal@lycos.com ${ }^{(3)}$ Alberta Research Council, Bioresource Technologies, Alberta Innovates, Technology Futures Vegreville, Vegreville, T9C 1T4 Alberta, Canada. E-mail: Jan.Slaski@albertainnovates.ca
\end{abstract}

\begin{abstract}
The objective of this work was to determine the geographic origin of the Madeiran common bean (Phaseolus vulgaris) gene pool. Phaseolin patterns of 50 accessions representing the diversity of common bean collected in Madeira, Portugal, and conserved in the ISOPlexis Germplasm Bank, were analysed using the Experion automated electrophoresis system, based on lab-on-a-chip technology. Five common bean standard varieties with typical phaseolin patterns were used to determine the phytogeographical origin of the Madeiran common bean accessions. Ninety two percent of the accessions exhibited a phaseolin pattern consistent with the one of common bean types belonging to the Andean gene pool, while the origin of the remaining $8 \%$ of the accessions was indistinguishable. The application of a similarity coefficient of $85 \%$, based on Pearson correlations, increases the number of accessions with uncertain pattern. The analytical approach used permitted the determination of the origin of the common bean gene pool, which is Andean in $98 \%$ of the cases, and clustering of the observed variability among the Madeiran common beans.
\end{abstract}

Index terms: Phaseolus vulgaris, gene pool, genetic variability, germplasm, lab-on-a-chip technology.

\section{Origem fitogeográfica de feijões da Madeira com base em perfis de faseolina}

\begin{abstract}
Resumo - O objetivo deste trabalho foi determinar a origem geográfica do "pool" genético do feijoeiro-comum (Phaseolus vulgaris) da ilha da Madeira, Portugal. Os perfis de faseolinas de 50 acessos que representam a diversidade do feijoeiro-comum coletados na ilha da Madeira, conservados no banco de germoplasma ISOPlexis, foram analisados por meio do sistema de eletroforese automática Experion, baseado na tecnologia "lab-on-a-chip". Cinco variedades padrão de feijoeiro, com perfis típicos de faseolina, foram usadas para determinar a origem fitogeográfica dos acessos de feijoeiro-comum da ilha da Madeira. Noventa e dois por cento dos acessos exibiram um perfil consistente com o dos tipos pertencentes ao "pool" genético Andino, enquanto não foi possível determinar a origem de $8 \%$ dos acessos restantes. A aplicação de um coeficiente de similaridade de $85 \%$, com base em correlações de Pearson, aumentou o número de acessos com perfil incerto. A abordagem analítica utilizada permitiu determinar a origem andina do "pool" genético em $98 \%$ dos casos, e o agrupamento da variabilidade observada entre os feijões da Madeira.
\end{abstract}

Termos para indexação: Phaseolus vulgaris, pool genético, variabilidade genética, germoplasma, tecnologia lab-on-a-chip.

\section{Introduction}

Common bean denominates an undetermined number of species of the genus Phaseolus, tribe Phaseoleae, family Fabaceae (Leguminosae), subfamily Faboidea (Lackey, 1981). Among them, Phaseolus vulgaris (L.) is the most important staple food crop in several countries, providing significant amounts of protein, fibers, minerals and vitamins (Hu et al., 2006).

Wild bean genetic resources were originated from two major gene pools, the Mesoamerican and the Andean, and one or two minor gene pools in the northern Andes (Koenig \& Gepts, 1989). Beebe et al. (2000), using RAPD analysis, identified a

Pesq. agropec. bras., Brasília, v.45, n.8, p.863-871, ago. 2010 
third common bean group possessing climbing growth behaviour, designated as the Guatemala race (Araya, 2003).

Seed size, used to determine common bean phytogeographic origin, is a parameter that suffers the influence of environmental factors and, thus, it is not a reliable criterion to determine the origin of the common bean gene pools. Therefore, Singh et al. (1991) proposed the utilization of storage proteins and isozymes patterns to determine common bean gene pools. Although the effects of environmental factors on seed protein content are not always avoidable (Vargas et al., 2000), analysis of phaseolins is widely used to determine sample origins (Gepts \& Bliss, 1988) and to evaluate germplasm collections (Logozzo et al., 2007).

Gepts et al. (1986) and Singh et al. (1991) showed that the cultivars or varieties from the Mesoamerican group possess phaseolin patterns of the Sanilac (S) and Boyaca (B) types, whereas those from their Andean counterparts have the Tendergreen (T), Contender (C), and Pampa (H) phaseolin types.

Phaseolus vulgaris has been introduced in Europe from both Andean and Mesoamerican domestication centres (Araya, 2003). Similarly to the Portuguese mainland, a rich diversity of common beans has been identified on the Island of Madeira. The Madeiran agro-diversity is a consequence of multiple crop introductions that occurred since the beginning of colonization, in the $15^{\text {th }}$ century, and subsequent crop adaptation to specific agroclimatic and edaphic conditions (Carvalho et al., 2008; Santos et al., 2009).

Little is known about the origin of common beans introduced in Madeira, but there are strong indications that this crop was initially brought to the Island by the settlers in the $17^{\text {th }}$ century from Brazil and South America (Silva \& Meneses, 1984).

Using Micro fluidic technology, in this case, the Experion automated electrophoresis system, it is possible to automatically run every step of the gel electrophoretic separation, with the advantage of allowing the analysis of a larger population of proteins and the delivery of accurate and reproducible sizing and relative quantities of each protein band (Nguyen \& Strong, 2005), with small sample sizes and volume of reagents (Bradová \& Matějová, 2008). Besides these advantages over traditional SDS gels, this technique is more precise, faster and effortless, and exposes operators to lower quantities of dangerous chemicals. Elucidation of the phytogeographic origin of common bean germplasm is the first attempt to perform a comprehensive evaluation of this germplasm resource grown on the Archipelago of Madeira. The determination of the similarity between germplasm accessions based on the seed storage protein polymorphism could be a valuable contribution to the overall evaluation of the Madeiran common bean collection.

The aim of this work was to determine the geographic origin of the Madeiran common bean gene pool, based on analyses of phaseolin patterns using the microfluidic technology.

\section{Materials and Methods}

The seed storage protein polymorphism of 50 accessions of common beans previously identified to the species level, using the dichotomic keys recommended by Freytag \& Debouck (2002), were analysed in 2009. Seed samples were obtained from the ISOPlexis Gene Bank collection at the Universidade da Madeira. For the phaseolin analysis, five standard cultivars of Phaseolus vulgaris - Andean, Tendergreen (T), Contender (C), Pampa (H); Mesoamerican, Sanilac (S) and Boyaca (B) - were used as outgroups to identify the phaseolin types. The Misión Biológica de Galicia (MBG), Spain, provided these standards.

To ensure that the common bean accessions used in this study accurately reflect the crop diversity, several selection criteria, including geographic distribution on the Island, diversity of common names, as well as differences in size, shape and the coloration of seed coats, were taken into careful consideration.

Ten randomly selected seeds were used per accession code abbreviature (ISOP) to obtain a bulk mixture and to determine their phaseolin protein patterns. Seeds, after tegument and embryos removal, were dehydrated at $50^{\circ} \mathrm{C}$ for $12 \mathrm{~h}$ (Vargas et al., 2000) and grounded separately using a mill. The flour was stored in microcentrifuge tubes at $4^{\circ} \mathrm{C}$ until analysis. Phaseolin extraction was

Pesq. agropec. bras., Brasília, v.45, n.8, p.863-871, ago. 2010 
performed according to Wrigley (1995) and the International Seed Testing Association (2004), using a buffer composed of $6.25 \mathrm{~mL}$ Tris $(1.0 \mathrm{~mol} \mathrm{~L}-1$, $\mathrm{pH}=6.8), 10 \mathrm{~mL}$ glycerol, $12.05 \mathrm{~mL} \mathrm{H}_{2} \mathrm{O}$ and 2.0 g SDS, diluted with mercaptoethanol and $\mathrm{H}_{2} \mathrm{O}$ in a 17:3:40 (v/v) proportion. The buffer was added to flour in a $1: 25(\mathrm{w} / \mathrm{v})$ proportion. Individual seed extractions $(25-\mu \mathrm{L}$ aliquots) were mixed to obtain a bulk sample of the accession.

The phaseolin patterns of the composite samples were analyzed using the lab-on-a-chip microfluidic technology, with assistance of the Experion Pro260 automated electrophoresis system (Biorad, Hercules, USA). Phaseolin separation was performed according to the protocol described by the Biorad Pro260 kit.

The virtual phaseolin gels were analysed to identify geographical origin of the gene pools and to determine samples heterogeneity or similarity. The variability of the phaseolin patterns obtained in virtual gels from Experion was evaluated using the fingerprinting software from Biorad. Accessions similarities were calculated using the Pearson correlation, and were clustered using the UPGMA method, with the fingerprint II basic software from Biorad. A similarity coefficient (SC) of $85 \%$, calculated by the software based in confidence intervals originated from the Pearson correlations, was used for the determination of common bean accession phaseolin types.

\section{Results and Discussion}

The analysis of phaseolin patterns of the common bean accessions from the Island of Madeira showed that the standard Andean (Contender, Tendergreen, and Pampa) and Mesoamerican (Sanilac and Boyaca) cultivars exhibited different phaseolin fractions, ranging approximately from 40.0 to $67.0 \mathrm{kDa}$ (Figure 1). Analysis of the phaseolin patterns revealed that the ISOPlexis accessions were mainly related to the Contender and Tendergreen cultivars (Table 1). Different phaseolin patterns were detected among analysed common bean accessions. Ninety-two percent of the accessions possessed an Andean gene pool origin, with $56.0 \%$ of the samples showing a phaseolin pattern similar to $\mathrm{C}$ type $(\mathrm{cv}$.
Contender), while $36.0 \%$ of samples showed a $\mathrm{T}$ phaseolin pattern. This was expected, because the majority of the analysed accessions presented a

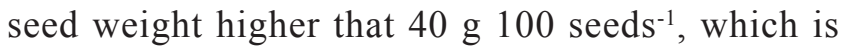
characteristic of beans with Andean origin (Voysest, 1983; Pereira et al, 2009). Only eight percent of the samples, which includes four accessions, exhibited an undetermined phaseolin type, although they were also from Andean origin (Table 2). Besides that, only 24 accessions - T (10 accessions) or C (14 accessions) types - reached the $85 \%$ similarity coefficient (SC), a threshold that permits a reliable classification in relation to one of the phaseolin types. The remaining 22 common bean accessions have shown SC below the threshold value, and their classification as the Tendergreen (8) or Contender (14) type was somewhat uncertain (Table 3).

Cluster analysis using the phaseolin patterns provided a dendrogram (Figure 2) that grouped all accessions in four major clusters (A to D). The clusters A and B were composed by accessions of the Tendegreen and Contender type, respectively, which showed the majority of their SC higher (Tendegreen) and lower (Contender) than 85. The $\mathrm{C}$ cluster grouped together the majority of common bean accessions similar to the Contender type with SC equal or higher than $85 \%$. The last cluster, subdivided in two sub-clusters, was the most heterogeneous and included the majority of the accessions with undetermined and T types, with similarities lower than $85 \%$. ISOP 00480 exhibited a distinctive position among analysed common bean accessions, which correlates with its specific small seed size.

Experion Pro260, using the common bean accessions and the standards, consistently reproduced the patterns of phaseolin. Its analysis shows protein fractions variation by number of bands, from four (cv. Contender) to six, and molecular weights (cvs. Sanilac, Pampa and Boyaca). These results do not confirm the ones from Lioi (1989), who observed negligible phaseolin polymorphism, suggesting that cvs. Sanilac and Contender possess four and three major subunits, respectively, while cvs. Tendergreen, Pampa and Boyaca have four major phaseolin subunits. Significant variations in the phaseolin frequencies, number of bands and 
molecular weights have been reported previously (Vargas et al., 2001). Vallejos et al. (1992) reported moderate, yet sufficient, polymorphism to discriminate between Mesoamerican and Andean common bean gene pools. The higher phaseolin polymorphism reported here can result from a higher resolution of the electrophoresis technique used, which can detect protein bands with less than $10 \mathrm{ng}$ of protein (Nguyen \& Strong, 2005).

The Andean gene pool dominates in Madeira with $92 \%$ of accessions, while merely $8 \%$ of accessions, although exhibiting proximity to the Andean gene pool, were classified as of uncertain origin (Table 1,2). The prevalence of the Andean gene pool among the Madeiran common beans is consistent with the historical records that point out Brazil as the origin of first crop introductions into the Island, and subsequently to the Portuguese mainland. Traces of the Mesoamerican germplasm are almost completely absent among the common bean landraces in the Island, which refutes the hypothesis of later introductions from Central or
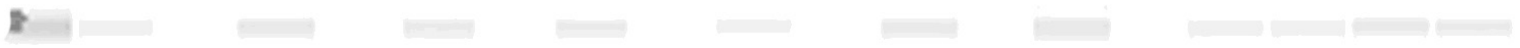

150.0

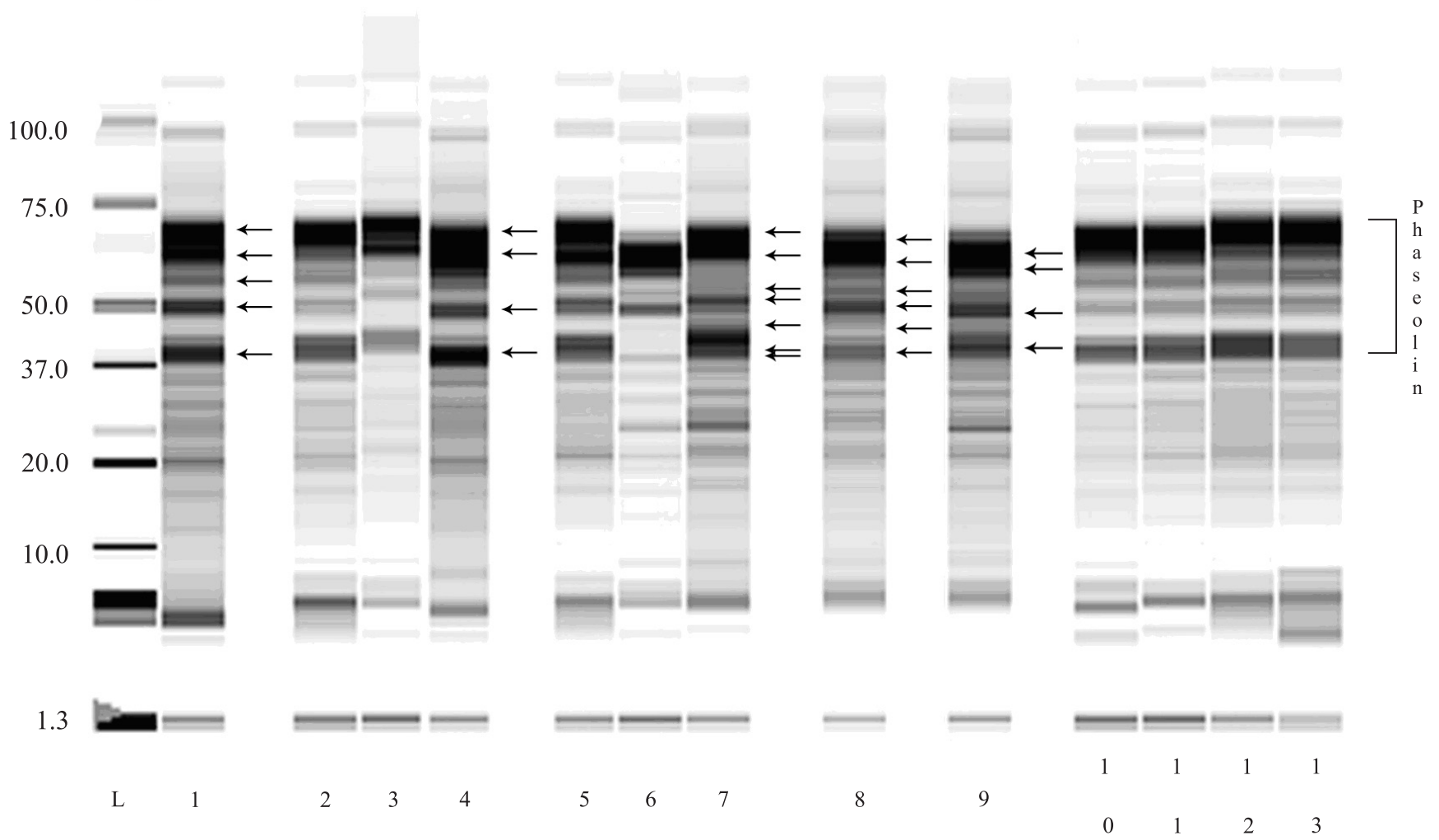

Figure 1. Biochemical characterization of the common bean (Phaseolus vulgaris) germplasm from the Island of Madeira, using the lab-on-a-chip technique. A virtual gel was created in the Experion Pro260 automated electrophoresis system (Biorad). Electrophoretical lanes: 1, standard cultivar Contender; 2, ISOP 00806; 3, ISOP 00670; 4, standard cultivar Tendergreen; 5, ISOP 00822; 6, ISOP 00480; 7, standard cultivar Pampa; 8, standard cultivar Boyaca; 9, standard cultivar Sanilac; 10-13, bean samples with uncertain phaseolin type, ISOP 00730, ISOP 00761, ISOP 00828, ISOP 00849, respectively. Arrows represent the bands of phaseolin in the various standards used in this study. 
Table 1. Geographical distribution of accessions, their vernacular names and gene pool origin of the Island of Madeira common bean (Phaseolus vulgaris) germplasm, according to their comparative analysis with the phaseolin patterns of Boyaca, Contender, Pampa, Sanilac and Tendergreen standards.

\begin{tabular}{|c|c|c|c|c|c|}
\hline \multirow[t]{2}{*}{ Accesion } & \multirow[t]{2}{*}{ Cultivar } & \multirow[t]{2}{*}{ County } & \multirow[t]{2}{*}{ Gene pool origin } & \multicolumn{2}{|c|}{ Phaseolin type $^{(1)}$} \\
\hline & & & & Higher than $85 \% \mathrm{SC}$ & Lower than $85 \% \mathrm{SC}$ \\
\hline 00459 & Canadiano & Santana & Andean & - & Tendergreen \\
\hline 00460 & Vergalheiro & Santana & Andean & Tendergreen & - \\
\hline 00463 & Corno de Carneiro & Santana & Andean & - & Contender \\
\hline 00478 & Filipe & Santana & Andean & - & Tendergreen \\
\hline 00480 & Preto & Santana & Andean & - & Tendergreen \\
\hline 00489 & Rasteiro & Santana & Andean & Tendergreen & - \\
\hline 00492 & Fava & Santana & Andean & - & Tendergreen \\
\hline 00497 & Touquinho & Santana & Andean & Tendergreen & - \\
\hline 00505 & Corno de Carneiro & Santana & Andean & - & Tendergreen \\
\hline 00508 & Milheiro & Santana & Andean & Tendergreen & - \\
\hline 00514 & Algarve & Santana & Andean & - & Contender \\
\hline 00519 & Touquinho & Santana & Andean & Contender & - \\
\hline 00521 & Faial & Santana & Andean & - & Contender \\
\hline 00528 & Faial & Santana & Andean & Contender & - \\
\hline 00534 & Vaginha & Santana & Andean & - & Contender \\
\hline 00541 & Manteiga & Santana & Andean & - & Contender \\
\hline 00668 & Preto & São Vicente & Andean & - & Contender \\
\hline 00670 & Branco Rasteiro & São Vicente & Andean & - & Contender \\
\hline 00679 & Vassoura Rasteiro & Porto Moniz & Andean & - & Contender \\
\hline 00712 & Vaginha & São Vicente & Andean & - & Contender \\
\hline 00713 & Vaginha Grossa & São Vicente & Andean & Contender & - \\
\hline 00719 & Feijão & São Vicente & Andean & Contender & - \\
\hline 00722 & Açores & São Vicente & Andean & Contender & - \\
\hline 00724 & Vermelho & São Vicente & Andean & Contender & - \\
\hline 00726 & Vassoura Rasteiro & São Vicente & Andean & Contender & - \\
\hline 00730 & Boneco & Ribeira Brava & Andean & - & $\mathrm{C} / \mathrm{T}$ \\
\hline 00731 & Rasteiro Vassoura & Ribeira Brava & Andean & Contender & - \\
\hline 00732 & Vaginha & São Vicente & Andean & Contender & - \\
\hline 00743 & Feijão & São Vicente & Andean & Contender & - \\
\hline 00744 & Feijão & São Vicente & Andean & Contender & - \\
\hline 00748 & Rajado & São Vicente & Andean & Contender & - \\
\hline 00749 & Vaginha & São Vicente & Andean & - & Tendergreen \\
\hline 00755 & Valinho & Porto Moniz & Andean & Tendergreen & - \\
\hline 00757 & Feijão & Porto Moniz & Andean & - & Contender \\
\hline 00760 & Vaginha & Porto Moniz & Andean & - & Contender \\
\hline 00761 & Alfarroba & Porto Moniz & Andean & - & $\mathrm{C} / \mathrm{T}$ \\
\hline 00764 & Rasteiro & Porto Moniz & Andean & - & Tendergreen \\
\hline 00770 & Vermelho & Porto Moniz & Andean & - & Contender \\
\hline 00773 & Gordo & Porto Moniz & Andean & - & Tendergreen \\
\hline 00777 & Catarino & Ribeira Brava & Andean & Tendergreen & - \\
\hline 00778 & Vagem Vermelha & Ribeira Brava & Andean & Tendergreen & - \\
\hline 00798 & Riscado de Vara & Calheta & Andean & - & Contender \\
\hline 00800 & Vara & Calheta & Andean & Contender & - \\
\hline 00806 & Corno de Carneiro & São Vicente & Andean & Contender & - \\
\hline 00809 & Vagem Vermelha & São Vicente & Andean & Contender &.- \\
\hline 00822 & Feijão de Pé & São Vicente & Andean & Tendergreen & - \\
\hline 00824 & Rajado & São Vicente & Andean & Tendergreen & - \\
\hline 00828 & Amarelo & São Vicente & Andean & - & $\mathrm{C} / \mathrm{T}$ \\
\hline 00829 & Feijão de Pé & São Vicente & Andean & Tendergreen & - \\
\hline 00849 & Corno de Carneiro & São Vicente & Andean & - & $\mathrm{C} / \mathrm{T}$ \\
\hline Standard & Tendergreen & MBG, Spain & Andean & - & - \\
\hline Standard & Contender & MBG, Spain & Andean & - & - \\
\hline Standard & Pampa & MBG, Spain & Andean & - & - \\
\hline Standard & Boyaca & MBG, Spain & Mesoamerican & - & - \\
\hline Standard & Sanilac & MBG, Spain & Mesoamerican & - & - \\
\hline
\end{tabular}

${ }^{(1)}$ Similarity coefficients (SC) calculated by the software Fingerprinting, based in confidences intervals originated from Pearson correlation. 
North America by emigrants and settlers. However, data surveyed in this work point out a considerable variability between Contender and Tendergreen phaseolin types. This variability can have different origins. Singh et al. (1991) and Paredes \& Gepts (1995) have detected hybrids showing the Andean morphology and comprising the Mesoamerican phaseolin types, as well as genotypes with the Mesoamerican morphology and the Andean phaseolin types.

Despite the fact that common bean is generally considered an autogamous species, the out-crossing rate could be as high as $60-70 \%$ (Wells et al., 1988) and, thus, it may contribute to the appearance of the uncertain phaseolin types, resulting from out-crossing between different common bean types inside or between the Andean and Mesoamerican gene pools (Beebe et al., 1997). Even the lowest out-crossing rates were sufficient to generate broad variability among common beans over the period of hundreds of years (Beebe et al., 1997).

The heterogeneity of phaseolin patterns can also be attributed to the high level of cross-pollination among wild beans (Gepts et al., 1986) or to hybridization processes (Singh et al., 1995). Fully fertile hybrids were observed not only in traditional common bean varieties from different regions (Broughton et al., 2003), but also between wild relatives (CWRs) and cultivars (Singh et al., 1995). However, it seems that this last source of variability does not have an important contribution to Madeira common bean diversity. As a result of the versatile out-crossing, $18.2 \%$ of the Portuguese common beans maintain

Table 2. Biochemical characterization ${ }^{(1)}$ of common bean (Phaseolus vulgaris) from the Island of Madeira based on the similarity of the phaseolin patterns to the standard cultivars.

\begin{tabular}{|c|c|c|c|c|c|c|c|c|}
\hline \multirow[t]{2}{*}{ Gene Pool } & \multicolumn{3}{|c|}{ Andean } & \multicolumn{2}{|c|}{ Mesoamerican } & \multicolumn{3}{|c|}{ Undetermined $^{(2)}$} \\
\hline & $\mathrm{C}$ & $\mathrm{T}$ & $\mathrm{H}$ & $\mathrm{S}$ & $\mathrm{B}$ & $\mathrm{U}^{\mathrm{A}}$ & $\mathrm{U}^{\mathrm{AM}}$ & $\mathrm{U}^{\mathrm{M}}$ \\
\hline Total accessions & & 46 & & & & & 4 & \\
\hline № accessinos by type & 28 & 18 & 0 & 0 & 0 & 4 & 0 & 0 \\
\hline Percent & 56.0 & 36.0 & 0 & 0 & 0 & 8.0 & 0 & 0 \\
\hline
\end{tabular}

${ }^{(1)}$ The accessions were classified according to the phytogeographic origin (Andean or Mesoamerican) and the phaseolin type of their gene pool: Contender (C), Tendergreen (T), Pampa (H), Sanilac (S) and Boyaca (B). ${ }^{(2)}$ The accessions with undetermined gene pool could be of the Andean $\left(\mathrm{U}^{\mathrm{A}}\right)$, Andean/Mesoamerican $\left(\mathrm{U}^{\mathrm{AM}}\right)$ or Mesoamerican $\left(\mathrm{U}^{\mathrm{M}}\right)$ origin. hybrid status (Tofiño et al., 2003). The relatively small number of accessions with uncertain phaseolin types ( $8 \%$ of accessions, Table 2) could suggest that a significantly lower level of out-crossing took place in Madeira when compared to other European regions (Broughton et al., 2003; Tofiño et al., 2003). The small number of accessions with undetermined bean type may also indicate a rather low number of introduction events.

The Contender type gene pool prevails on Madeira, comprising $52 \%$ of the accessions, followed by the type $\mathrm{T}$ accounting for $34 \%$ of the total accessions (Table 2). These observations are in accordance with other studies reporting prevalence of the Andean gene pool over the Mesoamerican ones among the European common beans. Logozzo et al. (2007) reported frequencies of $45.6 \%$ of the $\mathrm{T}$ type, $30.7 \%$ of the $\mathrm{C}$ type, and only $23.7 \%$ of the $\mathrm{S}$ type (the Mesoamerican gene pool), among European common beans. Similarly, Gepts \& Bliss (1988) observed the prevalence of the T type (72\%) among European cultivars. However, the C type gene pool, with 51.5 and $42.7 \%$, dominated among the common bean resources from Italy and the Iberian Peninsula, respectively (Logozzo et al., 2007). These results seem to indicate independent paths of common bean introduction between the South and other European regions.

Durán et al. (2005) observed that the frequency of the Tendergreen phaseolin allele increases in direct proportion with the reduction of the Sanilac phaseolin allele, which could explain the high frequencies of the $\mathrm{T}$ type in Europe. However, in Madeira, the $\mathrm{T}$ type is the second most important common bean type, and a direct relation between the Tendergreen and Sanilac phaseolin alleles was not observed, as the latter one is almost completely absent on the Island.

Table 3. Number and frequency of accessions (between brackets) with similarity coefficients (SC) to the phaseolin patterns of the standard cultivars higher or lower $85 \%$, according to the biochemical characterization of common bean (Phaseolus vulgaris) from the Island of Madeira.

\begin{tabular}{lcc}
\hline Phaseolin type & SC higher than $85 \%$ & SC lower than $85 \%$ \\
\hline Contender & $14(50.0)$ & $14(50.0)$ \\
Tendergreen & $11(55.5)$ & $8(44.5)$ \\
Contender/Tendergreen & $0(0.0)$ & $4(100.0)$ \\
\hline
\end{tabular}




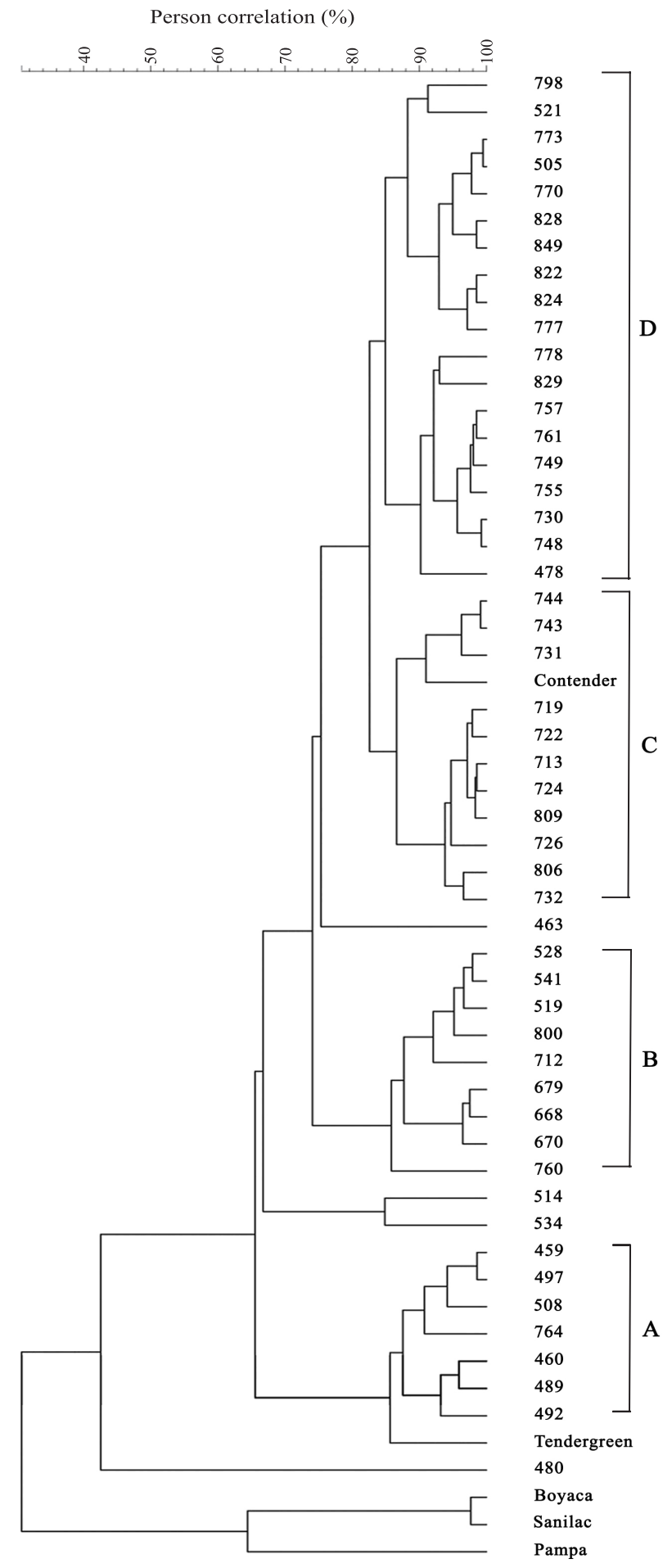

Figure 2. Cluster analysis of common bean (Phaseolus vulgaris) accessions based on phaseolin polymorphism, using the UPGMA method and the Pearson correlation distances with a limit of $85 \%$ confidence. Cluster A, accessions of the Tendergreen type with similarity coefficient (SC) higher than $85 \%$; cluster $\mathrm{B}$, accessions similar to the Contender type, with SC lower than $85 \%$; cluster $\mathrm{C}$, accessions of the Contender type, with SC equal or higher than $85 \%$; cluster D, accessions with the undetermined and the T types with SC lower than $85 \%$.
Contradictory data on the origin of the Portuguese common bean resources were reported. Rodiño et al. (2001) found that three-quarters of the accessions were of the Andean origin with the Contender and Tendergreen phaseolin types being the most frequent. Earlier, Escribano et al. (1998) reported that the Tendergreen and Pampa phaseolin types were more frequent than the Contender type among Portuguese commonbeans. The presence of several phaseolin types in the same region, such as the Iberian Peninsula, may suggest multiple paths of common bean introduction, from the Andes and Mesoamerica. Alternatively, the first common beans could have reached Europe from a region where both gene pools occurred already at the time of the European discovery of America, such as Cuba. The predominance of the $\mathrm{C}$ type of phaseolin in the Madeiran common beans suggest that this crop, on the Island and in Portugal mainland as well, could have the same initial source of common bean germplasm, but the number of introductions was lower in Madeira. On the other hand, the absence of the Mesoamerican phaseolin types in the Madeiran common beans might imply that the introduction of the crop germplasm to Madeira occurred prior to the continent.

\section{Conclusions}

1. The majority of Madeiran local common bean resources belong to the Andean gene pool.

2. A higher phaseolin polymorphism is present in the Madeiran common bean germplasm than reported in the literature, probably resulting from the higher resolution of the electrophoresis technique used.

3 . The relatively small number of accessions found with uncertain phaseolin types suggest that a significantly lower level of out-crossing, hybridisation and recombination took place on Madeira, when compared to other European regions.

4. The small number of accessions with undetermined gene pool may also indicate a rather low number of introduction events.

5. The predominance of the phaseolin $\mathrm{C}$ type in the Madeiran common beans suggests that the Island and Portugal mainland germplasm could have the same initial source, but the number of introductions was lower in Madeira. 


\section{Acknowledgements}

To the Fundação para a Ciência e Tecnologia; to European Union INTERREG IIIB program of the European Regional Development Fund; to the Madeiran farmers, who assisted with the sample collection; to all Germobanco project partners, for the support; to the Misión Biológica de Galicia, for the cultivar standards.

\section{References}

ARAYA, C.M. Coevolución de interacciones hospedante-patógeno en frijol. Fitopatologia Brasileira, v.28, p.221-228, 2003.

BEEBE, E.; SKROCH, P.W.; TOHME, J.; DUQUE, M.C.; PEDRAZA, F.; NIENHUS, J. Structure of genetic diversity among common bean landraces of Middle American origin based on correspondence analysis of RAPD. Crop Science, v.40, p.264-273, 2000 .

BEEBE, S.; TORO, O.C.; GONZÁLEZ, A.V.; CHACÓN, M.I.; DEBOUCK, D.G. Wild-weed-crop complexes of common bean (Phaseolus vulgaris L., Fabaceae) in the Andes of Peru and Colombia, and their implications for conservation and, breeding. Genetic Resources and Crop Evolution, v.44, p.73-91, 1997.

BRADOVÁ, J.; MATĚJOVÁ, E. Comparison of the results of SDS PAGE and chip electrophoresis of wheat storage proteins. Chromatographia, v.67, p.83-88, 2008.

BROUGHTON, W.J.; HERNANDEZ, G.; BLAIR, M.; BEEBE, S.; GEPTS, P.; VANDERLEYDEN, J. Beans (Phaseolus spp.) model food legumes. Plant Soil, v.252, p.55-128, 2003.

CARVALHO, M.Â.A.P. de; GANANÇA, J.F.T.; ABREU, I.; SOUSA, N.F.; SANTOS, T.M.M. dos; VIEIRA, R.M.C.; MOTTO, M. Evaluation of the maize (Zea mays L.) diversity on the Archipelago of Madeira. Genetic Resourses and Crop Evolution, v.55, p.221-233, 2008.

DURÁN, L.A.; BLAIR, M.W.; GIRALDO, M.C.; MACCHIAVELLI, R.; PROPHETE, E.; NIN, J.C.; BEAVER, J.S. Morphological and molecular characterization of common bean landraces and cultivars from the caribbean. Crop Science, v.45, p.1320-1328, 2005

ESCRIBANO, M.R.; SANTALLA, M.; CASQUERO, P.A.; DE RON, A.M. Patterns of genetic diversity in landraces of common bean (Phaseolus vulgaris L.) from Galicia. Plant Breeding, v.117, p.49-56, 1998.

FREYTAG, G.F.; DEBOUCK, D.G. Taxonomy, distribution, and ecology of the genus Phaseolus (Leguminosae-Papilinoideae) in North America, Mexico, and Central America. Texas: Forth Worth, 2002. 298p. (SIDA. Botanical Miscellany, 23).

GEPTS, P.; BLISS, F.A. Dissemination paths of common bean (Phaseolus vulgaris Fabaceae) deduced from phaseolin electrophoretic variability. II. Europe and Africa. Economic Botany, v.42, p.86-104, 1988.
GEPTS, P.; OSBORN, T.C.; RASHKA, K.; BLISS, F.A. Phaseolinprotein variability in wild forms and landraces of the common bean (Phaseolus vulgaris): evidence for multiple centers of domestication. Economic Botany, v.40, p.451-468, 1986.

HU, Y.; CHENG, Z.; HELLER, L.I.; KRASNOFF, S.B.; GLAHN, R.P.; WELCH, R.M. Kaempferol in red and pinto bean seed (Phaseolus vulgaris L.). coats inhibits iron bioavailability using an in vitro digestion/human caco-2 cell model. Journal of Agriculture and Food Chemistry, v.54, p.9254-9261, 2006.

INTERNATIONAL SEED TESTINGASSOCIATION. Verification of species/cultivar. In: ISTA. International rules for seed testing. Switzerland: ISTA, 2004.

KOENIG, R.; GEPTS, P. Allozyme diversity in wild Phaseolus vulgaris: further evidence for two major centers of genetic diversity. Theorotical and Applied Genetics, v.78, p.809-817, 1989.

LACKEY, J.A. Tribe 10. Phaseoleae DC, 1825. In: POLHILL, R.M.; RAVEN, P.H. (Ed.). Advances in legume systematics part 1. Surrey: Royal Botanic Gardens, Kew, 1981. p.301-327.

LIOI, L. Geographical variation of phaseolin patterns in an old world collection of Phaseolus vulgaris. Seed Science and Technolology, v.17, p.317-324, 1989.

LOGOZZO, G.; DONNOLI, R.; MACALUSO, L.; PAPA, R.; KNUPFFER, H.; ZEULI, P.S. Analysis of the contribution of Mesoamerican and Andean gene pools to European common bean (Phaseolus vulgaris L.) germplasm and strategies to establish a core collection. Genetic Resources and Crop Evolution, v.54, p.1763-1779, 2007.

NGUYEN, M.; STRONG, W. Performance comparison of the experionTM automated electrophoresis system and competing automated system for protein analysis, Rev A. 2005. Available at: <http://www.biocompare.com/Articles/ApplicationNote/1182/ Performance-Comparison-Of-The-Experion-AutomatedElectrophoresis-System-And-A-Competing-Automated-SystemForProtein-Analysis-Rev-A.html>. Accessed on: 31 Aug. 2010.

PAREDES, O.M.; GEPTS, P. Extensive introgression of Middle American germplasm into Chilean common bean cultivars. Genetic Resources and Crop Evolution, v.42, p.29-41, 1995.

PEREIRA, T.; COELHO, C.M.M.; BOGO, A.; GUIDOLIN, A.F.; MIQUELLUTI, D.J. Diversity in common bean landraces from south Brazil. Acta Botanica Croatica, v.68, p.79-92, 2009.

RODIÑO, A.P.; SANTALLA, M.; MONTERO, I.; CASQUERO, P.A.; DE RON, A.M. Diversity of common bean (Phaseolus vulgaris L.) germplasm from Portugal. Genetic Resourses and Crop Evolution, v.48, p.409-417, 2001.

SANTOS, T.M.M. dos; GANANÇA, F.; SLASKI, J.J.; CARVALHO, M.A.A.P. de. Morphological characterization of wheat genetic resources from the Island of Madeira, Portugal. Genetic Resourses and Crop Evolution, v.56, p.363-375, 2009.

SILVA, F.A.; MENESES, C.A. Elucidário madeirense. Funchal: Secretaria Regional de Cultura, 1984. 470p.

SINGH, S.P.; MOLINA, A.; GEPTS, P. Potential of wild common bean for seed yield improvement of cultivars in the tropics. Canadian Journal of Plant Science, v.75, p.807-813, 1995. 
SINGH, S.P.; NODARI, R.; GEPTS, P. Genetic diversity in cultivated common bean. I. Allozymes. Crop Science, v.31, p.19-23, 1991.

TOFIÑO, A.; OCAMPO, C.H.; TORO, O. Evidencia fenotípica y bioquímica de introgresión mesoamericana en accesiones de habichuela (Phaseolus vulgaris) cultivadas en centros secundarios de domesticación. Agronomia Colombiana, v.21, p.154-164, 2003.

VALLEJOS, C.E.; SAKIYAMA, N.S.; CHASE, C.D. A molecular marker-based linkage of Phaseolus vulgaris L. Genetics, v.131, p.733-740, 1992.

VARGAS, E.M.; MACAYA, G.; BAUDOIN, J.P.; ROCHA, O.J. Case studies on breeding systems and its consequences for germplasm conservation: 3 . Electrophoretic mobility of phaseolins in wild populations of Lima beans (Phaseolus lunatus L.) in the Central Valley of Costa Rica. Genetic Resources and Crop Evolution, v.48, p.109-120, 2001.

VARGAS, E.M.; MACAYA, G.; BAUDOIN, J.P.; ROCHA, O.J. Variation in the content of phaseolin in wild populations of lima beans (Phaseolus lunatus L.) in the Central Valley of Costa Rica. Plant Genetic Resources Newsletter, v.121, p.53-58, 2000.

VOYSEST, O. Variedades de frijol en América Latina y su origen. Cali: CIAT, 1983. 92p.

WELLS, W.C.; ISOM, W.H.; WAINES, J.G. Outcrossing rates of six common beans lines. Crop Science, v.28, p.177-178, 1988.

WRIGLEY, C.W. Identification of food grain varieties. St. Paul: American Association of Cereal Chemists, 1995. 283p.

Received on May 10, 2010 and accepted on June 22, 2010 